\title{
Seasonal changes in mRNA encoding for cell stress markers in the oyster Crassostrea gigas exposed to radioactive discharges in their natural environment
}

\author{
Emilie Farcy ${ }^{a, b}$, Claire Voiseux ${ }^{a}$, Jean-Marc Lebel ${ }^{b}$ and Bruno Fievet ${ }^{a,{ }^{\star}}$ \\ a Laboratoire de Radioécologie de Cherbourg-Octeville, Institut de Radioprotection et de Sûreté \\ Nucléaire/DEI/SECRE, Cherbourg-Octeville, France \\ ${ }^{\mathrm{b}}$ Laboratoire de Biologie et Biotechnologies Marines, Université de Caen Basse-Normandie, UMR 100 \\ Ifremer, Caen, France
}

*: Corresponding author : bruno.fievet@irsn.fr

\begin{abstract}
:
The North Cotentin area (Normandy, France) hosts several nuclear facilities among which the AREVA reprocessing plant of La Hague is responsible for controlled discharges of liquid radioactive wastes into the marine environment. The resulting increase in radioactivity is very small compared to natural radioactivity. However, concerns about environment protection prompted the scientific community to focus on the effects of the chronic exposure to low concentrations of radionuclides in non-human biota. This study contributes to the evaluation of the possible impact of radioactive discharges on the oyster Crassostrea gigas in the field. Real-time polymerase chain reaction was used to quantify the expression levels of genes involved in cell stress in the oyster. They included members of the heat shock protein family (Hsp70, Hsc72, Hsp90), superoxide dismutase (SOD) and metallothionein (MT). Times series measurements were built from periodic samplings in the natural environment in order to characterize the natural variability as well as possible seasonal fluctuations. The genes studied exhibited a general seasonal expression pattern with a peak value in winter. The data inversely correlated with seawater temperature and the nature of the relationship between gene expression and temperature is discussed. In parallel, oysters were collected in four locations on the French shores, exposed or not to radioactive liquid wastes from the nuclear facilities hosted in the North Cotentin. The comparison of data obtained in the reference location on the Atlantic coast (not exposed) and data from oysters of the English Channel (exposed) gave no evidence for any statistical difference. However, because of the complexity of the natural environment, we cannot rule out the possibility that other parameters may have masked the impact of radioactive discharges. This dense set of data is a basis for the use of the expression levels of those genes as biomarkers to address the question of the possible effects of chronic exposure of the oyster to low concentrations of radionuclides in controlled laboratory experimental conditions.
\end{abstract}

Keywords: Radioactive discharges; Seasonal variations; mRNA; Heat shock protein; Metallothionein; Superoxide dismutase; Crassostrea gigas 
Seasonal changes in mRNA encoding for cell stress markers in the oyster Crassostrea gigas exposed to radioactive discharges in their natural environment

\author{
FARCY Emilie ${ }^{1,2}$, VOISEUX Claire ${ }^{1}$, LEBEL Jean-Marc ${ }^{2}$ and FIEVET Bruno ${ }^{1}$ \\ 'Laboratoire de Radioćcologie de Cherbourg-Octeville. Institut de Radioprotection et de \\ Sûreté Nucléaire/DEI/SECRE. Cherbourg-Octeville, France. \\ ${ }^{2}$ Laboratoire de Biologie et Biotechnologies Marines. Université de Caen Basse- \\ Normandie. UMR 100 Ifremer. Caen, France.
}

Corresponding author: Bruno Fiévet, Ph.D., Institut de Radioprotection et de Sûreté Nucléaire, DEJ/SLCRE/LRC, Rue Max Pol Fouchet, BP10, 50130 Cherbourg-Octeville, France.

Email: bruno.fievet@irsn.fr.

Telephone: (33) 233014101 Fax: (33) 233014130

Keywords: Radioactive discharges, Seasonal variations, mRNA, heat shock protein, metallothioncin, superoxide dismutase, Crassostrea gigas

\begin{abstract}
The North Cotentin area (Normandy, France) hosts several nuclear facilities among which the AREVA reprocessing plant of La Hague is responsible for controlled discharges of liquid radioactive wastes into the marine environment. The resulting increase in radioactivity is very small compared to natural radioactivity. However, concerns about environment protection prompted the scientific community to focus on the effects of the chronic exposure to low concentrations of radionuclides in non-human biota. This study contributes to the evaluation of the possible impact of radioactive discharges on the oyster Crassostrea gigas in the field. Real-time polymerase chain reaction was used to quantify the expression levels of genes involved in cell stress in the oyster. They included members of the heat shock protein family (Hsp70, Hsc72, Hsp90), superoxide dismutase (SOD) and metallothionein (MT). Times series measurements were built from periodic samplings in the natural environment in order to characterize the natural variability as well as possible seasonal fluctuations. The genes studied exhibited a general seasonal expression pattern with a peak value in winter. The data inversely correlated with seawater temperature and the nature of the relationship between gene expression and temperature is discussed. In
\end{abstract}


parallel, oysters were collected in four locations on the French shores, exposed or not to radioactive liquid wastes from the nuclear facilities hosted in the North-Cotentin. The comparison of data obtained in the reference location on the Atlantic coast (not exposed) and data from oysters of the English Channel (exposed) gave no evidence for any statistical difference. However, because of the complexity of the natural environment, we cannot rule out the possibility that other parameters may have masked the impact of radioactive discharges. This dense set of data is a basis for the use of the expression levels of those genes as biomarkers to address the question of the possible effects of chronic exposure of the oyster to low concentrations of radionuclides in controlled laboratory experimental conditions.

\section{INTRODUCTION}

The North Cotentin area (Normandy, France) hosts several nuclear facilities, including the AREV $\Lambda$ reprocessing plant in La Hague, which is responsible for controlled discharges of liquid radioactive waste into the marine environment. These discharges result in measurable amounts of a few artificial radionuclides in the vicinity of the input source. The resulting increase in radioactivity is small compared to natural radioactivity. However, oyster farms are located in this area and the oysters may be slightly labelled. Recently, concerns about environmental protection have prompted the scientific community to focus on the effects of ionizing radiation on non-human biota. This study contributes to the evaluation of the possible impact of radioactive discharges on the oyster

Crassostrea gigas in the field. Since oyster physiology is known to be strongly influenced by the reproductive cycle, its response to a given stress is likely to fluctuate seasonally. In this context of chronic exposure, it was neccssary to address the question of possible seasonal fluctuations in the oysters' responses.

We monitored seasonal changes in the expression of genes involved in the response to cell stress in different locations, which either were or were not exposed to artificial radionuclides released by the nuclear industry. We focussed on mRNA levels of particular genes, known, on the basis of radiobiology literature, to be involved in the response to 
ionizing radiation. The genes dealt with in this study are involved in the chaperone protein function: the heat shock protein family (Hsp70, Hsc72, Hsp90) (Ehrhart et al., 1988; Davidoff et al., 1992; Sierra-Rivera et al., 1993; Matsumoto et al., 1995; Kang et al., 2002; Calini et al., 2003); and in regulation of oxidative stress: superoxide dismutase (SOD), metallothionein (MT) (Greenstock et al., 1987; Yamaoka et al., 1994; Otero et al., 1996; Cai et al., 1999; Cai and Cherian, 2003; Guo et al., 2003). Real-time polymerase chain reaction (PCR) was used to quantify mRNA encoding for these markers in comparison with mRNA encoding for actin, as a reference gene. RNA was extracted from whole oyster soft part homogenates as well as from isolated gills. Samples were collected monthly and quarterly on the French Atlantic and Channel coasts in order to build time series measurements of radionuclide labelling and gene expression. Statistical analysis of these data was performed, first to characterize the ranges of fluctuations in these markers in the natural environment, as well as possible seasonal variations, and secondly, to compare populations that either were or were not exposed to radioactive discharges by the AREVA reprocessing plant.

\section{METHODS}

\section{2-1 Sampling}

Oysters were obtained from oyster farms located in the sampling sites. Attention was paid to ensure that all of the oysters were diploid, 3-4 years-old, had spent their entire growing life in the farm and had been removed from seawater just before sampling.

For radionuclide concentration measurements, oysters were purchased monthly in St- 
Vaast (STV) from July 2002 to February 2005, and quarterly in Asnelles (ASN), Cancale (CCL) and Carnac (CRC) (Fig. 1) from March 2004 to January 2005. The whole of the soft parts was separated from the shell and dried at $90^{\circ} \mathrm{C}$ to a constant dry weight and then ground into fine powder. The dry material was conditioned in a suitable geometry for gamma spectrometry analysis. On a few samples only, another aliquot of dry material was calcined at $450^{\circ} \mathrm{C}$ and the ash was sent for americium, curium and plutonium radiochemistry and alpha spectrometry analysis by the Environmental Radioactivity Measurement I.aboratory (IRSN, Orsay, France).

For gene expression experiments, oysters were collected monthly in St-Vaast and quarterly in Asnelles, Cancale and Carnac between January 2004 and September 2005. At these four locations, the gills of 20 oysters and all the soft parts of 20 other oysters were immediately dissected, on the spot after sampling. $\Lambda$ fter dissection, the samples were immediately frozen in liquid nitrogen. Back at the laboratory, the oyster extracts were crushed in a ball crusher, in buckets cooled in liquid nitrogen. After this step, five individual oysters were pooled together as one.

\section{2-2 RNA extraction}

Total RNA was extracted with TRI REAGENT according to the manufacturer's instructions (Sigma-Aldrich). The amount and quality of RNA was quantified by measurement of absorbance at 260 and $280 \mathrm{~nm}$ in a UV-spectrophotometer. To discard genomic DNA contamination, total RNA was digested with DNAse I Amplification Grade (Sigma-Aldrich) and an aliquot of DNAse-treated RNA was then subjected to a PCR with actin primers to check the absence of genomic DNA. 


\section{2-3 Real-time PCR and Analysis}

Reverse transcription (RT) was carried out using $500 \mathrm{ng}$ of total RNA treated with DNAse I, 500 ng random primers (Promega), 200 U Moloney murine leukaemia virus (M-MLV) reverse transcriptase (Promega), $12.5 \mu$ moles RNAse-free dNTP, and $25 \mathrm{U}$ recombinant RNAsin (Promega). The sequences of the forward and reverse primers were designed using Primer3 software (http://frodo.wi.mit.edu/cgi-bin/primer3/primer3_www.cgi) and synthesized by Eurogentec (Table 1). Their efficiency was tested using the standard curve method. A dilution range was performed for each pair of primers to obtain a standard curve by plotting the cycle threshold as a function of the log of the total amount of starting RNA (reverse-transcripted). Primer pairs showing a good efficiency level $(100 \pm 5 \%)$ on a range of cDNA concentrations of four orders of magnitude were kept for quantification.

Real-time PCR was performed in a MiQ Cycler (Biorad). All determinations were carried out in duplicate. Controls of no template cDNA were included in PCR experiments. Amplification was carried out in $96-$ well plates, in a total volume of $15 \mu$ l containing $7.5 \mu 1$ of $2 \mathrm{X}$ iQ $\mathrm{SYBR}^{\circledR}$ Green supermix (Biorad), each primer (500 nM final) and cDNA samples obtained from reverse transcription of $5 \mathrm{ng}$ of total RNA. Amplification conditions were 40 cycles of $15 \mathrm{sec}$ at $95^{\circ} \mathrm{C}$ and $45 \mathrm{sec}$ at $60^{\circ} \mathrm{C}$, followed by the protocol for the melting curve: 80 cycles of $10 \mathrm{sec}$ with an increase of $0.5^{\circ} \mathrm{C}$ between each cycle from $55^{\circ} \mathrm{C}$ to $95^{\circ} \mathrm{C}$. The melting curve was used to check whether the amplification products had the expected Tm.

\section{2-4 Normalization of $m R N A$}


A preliminary task was to specifically address the choice of the reference gene to quantitatively express gene expression. To analyse gene expression level, mRNA quantities were normalized to actin mRNA, a cytoskeleton protein, GAPDH mRNA, a gene involved in glycolysis often used as reference, and $18 \mathrm{~S}$ ribosomal RNA, which accounted for total RNA, in order to check the influence of the reference gene. Seasonal expression patterns were found to be very similar when normalized to these three classically used reference RNAs (data not shown) and actin mRNA was finally used for all subsequent normalization.

\section{2-5 Seawater temperature measurements}

The English Channel is characterized by exceptionally strong tidal currents and low depth, so the water column is considered homogenous. Temperature was measured up-tide from the shore monthly with a digital thermometer (precision: $0.1^{\circ} \mathrm{C}$ ). The measurements were performed in Goury, near the St-Vaast sampling site.

\section{2-6 Statistical analysis}

Statistical analysis was carried out using Statgraphics Centurion XV software (StatPoint, Inc., http://www.statgraphics.com/). Values were expressed as means $\pm \mathrm{SD}$ of four pooled oyster extracts from 5 individuals. Statistically significant differences between two samples were determined using a Mann-Whitney non-parametric rank test; ${ }^{*} \mathrm{p} \leq 0.05$ was accepted as significant. Linear regression analysis was performed to estimate correlations (r) between water temperature versus mRNA fluctuations.

A principal component analysis was carried out, using SPAD 6.0 software (SPAD 
TEST\&GO, http:/www.testandgo.com/), to characterize the main trends of the data set with respect to all descriptors: gene, month, type of extract and location.

\section{RESULTS}

\section{3-1 Radionuclide concentrations}

Gamma spectrometry analysis of all four locations of oyster samples (whole solt parts) showed the presence of natural ${ }^{40} \mathrm{~K}$ every month, in the range $316-452 \mathrm{~Bq} \cdot \mathrm{kg}^{-1}$ dry weight (dw). In CCL, ASN (remote from AREV $\Lambda$ reprocessing plant liquid waste input) and CRC (Atlantic coast, unexposed to discharges from AREVA plant), no artificial radionuclides were detected by gamma spectrometry. In STV, ${ }^{60}$ Co was detected 9 times and ${ }^{137} \mathrm{Cs}$ was detected 3 times, out of 32 monthly samplings between Jul-02 and Feb-05, at concentrations generally less than $0.2 \mathrm{~Bq} \cdot \mathrm{kg}^{-1} \mathrm{dw}$ and $0.5 \mathrm{~Bq} \cdot \mathrm{kg}^{-1} \mathrm{dw}$, respectively (Table 2). Months when no artificial radionuclides were detected by gamma spectrometry are not shown in Table 2 .

Radiochemistry of transuranic elements and alpha spectrometry analysis was performed on one sample from $\mathrm{CRC}$ (Atlantic coast), one sample from CCL and three samples from STV. The results expressed in Bq. $\mathrm{kg}^{-1} \mathrm{dw}$ are presented in table 3 and though there were very few data, it can be noted that, compared to the background level in CRC (Atlantic coast), a slight labelling could be detected in the Cotentin locations.

\section{3-2 Water temperature}


Seawater temperature was measured in the North Cotentin area, close to the AREVA reprocessing plant. Maximum water temperatures were reached during the summer period (August-Scptember) with values around $18^{\circ} \mathrm{C}$, while minimum values of $7^{\circ} \mathrm{C}$ werc observed in February. These cold periods (below $10^{\circ} \mathrm{C}$, grey bands) are outlined in figures 2 and 3.

\section{3-3 Seasonal variations of stress-inducible gene expression}

Monthly recorded values of mRNA levels in gills and whole soft parts in oysters from STV between January 2004 and September 2005 are shown in figure 3. Genes involved in protein refolding are Hsp70 (Fig. 3a), HIsc72 (Fig. 3b) and Hsp90 (Fig. 3c), and those involved in oxidative stress regulation are SOD (Fig. 3d) and MT (Fig. 3e).

For all five stress-inducible genes, animals collected monthly in STV showed seasonal fluctuations in mRNA levels in both isolated gills and whole soft parts. Firstly, it appears that the mRNA level peaked in the winter period: January-February-March 2004 and February-March-April 2005. For each gene studied and for both gills and soft part homogenate, the Mann-Whitney test was performed on pairs of maximal (winter, summer) and minimal (September) values. In figure 3, paired values were linked with a solid line in whole parts and a dotted line in gills.

Another critical period of the annual cycle was found in the summer between June and August, during which whole soft part values exhibited a significant increase compared to May and September mRNA levels. The lowest mRNA levels were generally observed in May and September in both gills and soft part homogenate. The ratio of this summer 
mRNA level increase was generally smaller than the ratio of winter increase, except for SOD and Hsc72, which exhibited particularly strong increases in the summer. The latter genes showed a 4-fold significant increase $(p<0.05)$ of mRNA level in June-July-August 2004 and June-July 2005 in the whole soft parts compared to May and September of the same year. This summer increase in mRNA level was not observed in gills.

\section{3-4 Relationship with temperature}

The above results showed that mRNA levels of stress-inducible genes apparently exhibited a temperature-related pattern. Indeed, the temperature hits its low-point below $10^{\circ} \mathrm{C}$ when mRNA levels were at their highest.

In order to study whether stress-induced genes' mRNA levels are related to temperature, a linear regression analysis between mRNA levels in STV and water temperature was performed and the correlation coefficicnts were calculated in both whole soft parts and gills (Table 4). The inverse correlation between seawater temperature and mRNA levels in STV was generally better in the gills than in the whole soft parts. This was expected to be due to the summer increase observed in whole soft parts and not in gills.

\section{3-5 Comparison between locations}

In order to compare populations that either are or are not exposed to radioactive discharges by the AREVA reprocessing plant, we studied the differences between CRC (reference site) and the other locations at four periods of the year: January, March, June and September. Values of mRNA levels of stress-inducible genes in whole soft parts of oyster from the four sampling sites (CRC, CCL, ASN, STV) are shown in figure 4 for January, 
March, June, September 2004 and January, March, June 2005: Hsp70 (Fig. 4a), IIsc72 (Fig. 4b), Hsp90 (Fig. 4c), SOD (Fig. 4d) and MT (Fig. 4c). For each gene studied, a Mann-Whitney test was performed between the values for CRC and each of the other three sampling locations (CCL, STV and ASN).

In animals collected in $\mathrm{CCL}, \Lambda \mathrm{SN}$ and $\mathrm{STV}$, the whole soft parts mRNA levels were most often closely similar to those measured in the oysters from CRC. Data obtained on the same studied genes, in isolated gills from different oysters, sampled at the same time, in the four locations, were similar (data not shown). Only very few statistically significant differences could be found between the four locations. These significant differences indicated either higher or lower values in one of the three locations (CCL, ASN and STV), compared to the unexposed site of $\mathrm{CRC}$. For the genes considered, the ratios between the lowest mRNA level in September and highest in January or March were similar in the four sites. The previously described seasonal pattern in STV was confirmed in CCL, ASN and CRC. However, the summer increase, previously described in the whole soft parts in STV, could not be observed in the three other locations with the current quarterly sampling frequency.

\section{3-6 Principal Component Analysis}

A Principal Component Analysis (PCA) was performed on the mean values of mRNA levels obtained in gills and whole soft parts for the five genes studied, the four sampling locations and the six months (March-04, June-04, September-04, January-05, March-05 and June-05).

The principal axes are constructed from the dispersion of the data for the quantitative parameters (gene expression). The correlation circle (Fig. 5) showed that all variables 
were negatively correlated to the first axis (size effect). The first two components represented $79 \%$ of the total variance. It was interesting to examine the correlation of these components with the genes (Table 5). The correlation among descriptors is given by the angle between descriptor axes. The closer to unity (unsigned value), the stronger the correlation. This correlation revealed that all genes explained component 1 well.

The illustrative parameters (location and month) are positioned a posteriori according to the existing principal axis. For each axis and each illustrative parameter, the test value expresses the statistical significance of the parameter's coordinate on this axis. The matrix of the test values is given in table 6 for the illustrative parameters (location, month). We can see that the parameter "month" was well represented on axis 1 (absolute test value>2), whereas the parameter "location" was not (absolute test-value $<2$ ). This means that, unlike the locations, the sampling months were significantly linked to the first axis, except for March 2004. Finally, axis 1 clearly separated data as a function of time and this first axis showed a strong contrast between winter and summer (Fig. 6). In table 6, axis 2 also revealed an opposition between September 2004 (test-value=-2.9) and June 2005 (testvalue=2.4). However, on this axis 2 , the test values did not allow for interpretation of the "location" parameter.

\section{DISCUSSION}

The main goal of this study was to compare oysters from locations that either are or are not exposed to liquid radioactive waste discharges in the marine environment. The Cotentin area in France is a typical example of the potential impact of the nuclear industry on the natural environment because this is where the La Hague AREVA reprocessing plant is sited. Dispersion of radioactive liquid discharges from the Cotentin area into the English 
Channel is well documented with respect to hydrodynamics and it has been shown to move towards the North Sea (see Bailly du Bois and Dumas, 2005 for a review). Among the four sampling locations, Carnac, located on the Atlantic coast, was thus used as the reference site. Concentrations of radionuclides in different biological compartments of the marine environment on the French Atlantic and the English Channel coasts between 1993 and 2003 were recently reviewed (Fiévet and Germain, 2004). Regarding gamma emitter radionuclides, we should point out that ${ }^{40} \mathrm{~K}$ was found in oyster soft parts from all four sampling locations. This is a natural radionuclide, present at background level. Labelling by AREVA liquid radioactive waste was detectable in St-Vaast, which is downstream of the plant discharge dispersal, with the presence of ${ }^{60} \mathrm{Co}$ and ${ }^{137} \mathrm{Cs}$. However, it should be recalled that part of the ${ }^{137} \mathrm{Cs}$ present in oysters in the Cotentin area is a result of atmospheric nuclear weapons tests which lasted up to the 70s (Fiévet and Germain, 2004). In any case, these artificial gamma emitter radionuclide concentrations are at least 3 orders of magnitude lower than natural ${ }^{40} \mathrm{~K}$. A few analyses of transuranic elements in oyster samples were performed in this work and the results showed that these alpha emitter radionuclides were detected on the Atlantic coast (Carnac). Their presence in the reference site is also a consequence of past atmospheric nuclear weapons tests. Labelling in oysters around the Cotentin Peninsula was clearly detected with up to 30 -fold higher alpha emitter concentrations than in Carnac. The marine environment is also characterized by the presence of ${ }^{210} \mathrm{Po}$, another element of natural origin (the result of natural ${ }^{238} \mathrm{U}$ decay). This natural alpha emitter radionuclide was analysed in oysters from the same sampling locations, and concentrations in soft parts were found in the $100-1000 \mathrm{~Bq} \cdot \mathrm{kg}^{-1} \mathrm{dw}$ range (Connan, personnal communication). Here again, the ratio of several orders of magnitude between artificial and natural alpha emitter radionuclide concentrations should be emphasized. The fluctuations of radionuclide concentrations in seawater in the English 
Channel are well documented. Many measurements and accurate models have been developed and fine-tuned to account for dispersion of liquid waste (Bailly du Bois and Dumas, 2005). At the distance from the source of input where St-Vaast is located, radionuclide concentrations are quite stable compared to the vicinity of the AREVA pipe where sharp changes reflect the kinetics of releases by the plant (Fiévet and Plet, 2003; Fiévet et al., in press). In Cancale and Asnelles, because of detection limits, present gamma spectrometry data provided no evidence for the labelling of oysters by radioactive discharges from the AREVA reprocessing plant. However, in past decades, radioecology studies in the English Channel, considering other marine indicators and/or other radionuclides, have shown that these two locations are in the area of influence of these discharges. From this brief overview of radioecology, the impact of the nuclear industry on oysters in the English Channel is expected to be fairly constant and probably low, especially considering natural radioactivity. Extremely sensitive tools are thus required to conduct research into any possible impact.

Most literature available on the effects of radiations on cellular functions is devoted to mammals, exposed to high and acute doses. Few studies have conducted research into the effects of chronic exposure of lower vertebrate and invertebrate species to low doses of ionizing radiation (Cooley, 1973; Baptist et al., 1975; Woodhead, 1977, Rackham and Whoodhead, 1984; Theodorakis and Shugart, 1998; Hinton, 2000; Mihok, 2004; Hagger et al., 2005; Jha et al., 2005) and none into mRNA. However, on the basis of radiobiological knowledge, one can focus on a number of cellular functions, expected to be involved in the response to ionizing radiation. Ionizing radiation results in radiolysis of water molecules, which produces reactive oxygen species (ROS), and more generally damage to potentially all molecules present, altering their functions. Cell responses to this damage 
involve chaperone proteins (Ehrhart et al., 1988; Davidoff et al., 1992; Sierra-Rivera et al., 1993; Matsumoto et al., 1995; Kang et al., 2002; Calini et al., 2003) and defence against oxidative stress (Greenstock et al., 1987; Yamaoka et al., 1994; Otero et al., 1996; Cai et al., 1999; Cai and Cherian, 2003; Guo et al., 2003), among others. The recent development of the real-time PCR technique following reverse-transcription makes it possible to quantify messenger RNA precisely and thus determine the expression level of specific genes. One key issue of using the real-time PCR technique is the choice of the reference RNA (Thellin et al., 1999; Goidin et al., 2001; Kim et al., 2003; Andersen et al., 2004; Ropenga et al., 2004; Bustin et al., 2005; Huggett et al., 2005; Wong and Medrano, 2005), this being particularly relevant for in situ studies with periodic mRNA level recording. We verified that the observed variation pattern of stress-inducible genes was not due to the variation of actin itself.

A prerequisite for the use of mRNA levels of genes as markers of oyster stress was to figure out their natural range of fluctuation to serve as a basis for all subsequent comparisons and to be able to assess the significance of observed changes.

In the entire data set obtained in STV, we observed overall high levels of mRNA between January and April in both gills and soft part homogenate. In whole soft parts, a secondary increase in mRNA level was noticed in the summer period between June and August, especially for SOD and Hsc72 mRNA. Two distinct hypotheses could be proposed to explain these fluctuations: either they were seasonal or they reflected changes in the source of a local pollutant such as radionuclides released by the AREVA plant or another stressor, which may or may not have been anthropogenic. The hypothesis of changes in the impact of liquid radioactive waste from the AREVA plant seemed unlikely for the 
following reasons: at that distance from the point of release, radionuclide concentrations in seawater are quite stable and radionuclide transfer kinetics between seawater and biological compartments smooth out changes in marine species even further (Fiévet and Plet, 2003; Fiévet et al., in press). Another argument came from the comparison between data obtained in St-Vaast and the three other sampling locations, including the reference site on the Atlantic coast, which provided no evidence for any statistically significant systematic difference in St-Vaast (further discussed below). As far as fluctuations of other possible pollutants are concerned, pressure by unidentified sources of environmental annual cyclic stressor obviously cannot be ruled out. Data from the seawater qualitymonitoring program suggested that the four locations did not strongly differ regarding metals, polycyclic aromatic hydrocarbons (PAH) and polychlorinated biphenyl (PCB) (Ifremer, 2005a; Ifremer, 2005b; Ifremer, 2005c). The hypothesis of seasonal fluctuations is supported by the following arguments: synchronicity between winter mRNA level peaks and seawater winter temperature was observed repeatedly over the whole time period and the main seasonal trend was confirmed with quarterly samplings in all four locations studied.

On the other hand, a direct role of temperature on the mRNA level of stress-inducible genes cannot be asserted from the data obtained, even if $60 \%$ to $80 \%$ of the variance was explained using the hypothesis of an inverse linear relationship, depending on the gene and the oyster extract considered. Indeed, mRNA levels of stress-related genes may be influenced by physiological processes other than stress, which are in phase with seasonal temperature changes. For example, the annual metabolic cycle of oysters is largely driven by reproduction and linked to temperature. We observed that the period of increase in the mRNA level (January-February-March) coincided with gametogenesis, more precisely the stage in which the oocyte grows in diameter (Lango-Reynoso et al., 2000) and the reserve 
tissue increases (Heude-Berthellin, 2000). Moreover, we observed that mRNA levels fell in August-September every year $(2004,2005)$ : this was in phase with the end of the spawning period. This decrease after the spawning period was observed in Corbicularia, with minimum values of MT protein concentrations observed after the spawning period (Baudrimont et al., 1997).

Comparing the different locations was a major goal of this study. On the basis of quarterly samplings, seasonal fluctuations were observed in all four sites with similar magnitude. Mann-Whitney test comparisons between the reference site (Carnac, Atlantic coast) values and the English Channel sites values pointed out some scattered statistically significant differences. However, no clear tendency (increase or decrease) in mRNA levels could be associated with the exposure of sampling locations to liquid radioactive waste from the AREVA reprocessing plant in La Hague. We cannot exclude the possibility that differences could be hidden or counteracted by other parameters. However, in the end, our data turned out to appear strongly influenced by the season, even though we focused on artificial radionuclides in North Cotentin in this study. A principal component analysis was performed to look further into this extensive dataset (sampling locations, genes, sampling quarters). This multivariate analysis showed that the dataset was highly structured by seasonality, with a strong contrast between winter months (January, March) and summer months (June, September), for all four locations. Neither of the first two axes was generated by the "location" parameter. This meant that this descriptor did not strongly structure the dispersion of the data.

Since the genes considered in this study are presumably influenced by a variety of biotic and abiotic factors, one may wonder whether any seasonal patterns exist. Interestingly, the 
genes studied showed the same general fluctuation pattern. Most data available from the literature on environmental ecotoxicological studies regarding those stress markers were obtained at the level of proteins or physiological functions. However, it is worth briefly comparing existing results with the actual pattern observed at transcriptional level.

Regarding oxidative stress, previous studies showed a correlation between antioxidant defences and seasonality, with respect to the reproductive period and food intake (Viarengo et al., 1991; Solé et al., 1995). In particular, in the summer, temperature and food availability induce oxygen consumption and cellular oxyradical generation, which are offset by increasing antioxidant defences. Viarengo et al. (1991) suggested that the decrease in activity of the antioxidant defence system during the winter could be directly responsible for an enhanced susceptibility of mussels to oxidative stress in this period. Similarly, Sheehan and Power (1999) emphasize that oxidative stress is a highly seasonal phenomenon in bivalves. In addition, the modulation of oxidative stress by environmental pollutants obviously interferes and makes interpretation of biomonitoring data difficult. The fluctuation pattern obtained for Crassostrea gigas SOD mRNA in this study corroborates the general consideration that the summer is a stressful period with a high level of oxidative stress. But we also underlined that the colder period between January and April was characterized by even higher SOD mRNA levels, which we cannot currently explain, on the basis of literature.

Metallothionein has been widely used as a biomarker in field and laboratory studies, in particular in relation to its function in metal detoxification (Baudrimont et al., 1997; Ringwood et al., 1998; Geffard et al., 2001, 2002, 2005; Tanguy et al., 2002; Irato et al., 2003; Bodin et al., 2004; for a review, see Amiard et al., 2006). MT was also clearly shown to be involved in scavenging free radicals during oxidative damage in vertebrates 
(Sato and Bremner, 1993; Chubatsu and Meneghini, 1993; Dalton et al., 1994; Cai et al., 1999; You et al., 2002). In molluscs, the antioxidant role of metallothionein has been shown in bivalves and gastropods (Roesijadi et al., 1997; Anderson et al., 1999; Viarengo et al., 1999; Viarengo et al., 2000; Leung and Furness, 2001; Cavaletto et al., 2002; Bebianno et al., 2005), providing evidence that metallothionein is effective in protecting cells and the entire organism against oxidative stress. Amiard et al. (2006) discussed the confounding factors affecting concentrations of MT: temperature (Serafim et al., 2002) and salinity (Leung et al., 2002). Among confounding factors, the reproductive cycle was found to be strongly correlated with the annual variation in metallothionein level of the Asiatic clam (Corbicula fluminea) in an unpolluted site in France (Baudrimont et al., 1997). Interestingly, we observed that MT mRNA levels fell in August-September every year $(2004,2005)$ in phase with the end of the spawning period in the oyster.

Concerning the Hsp family gene, increased levels of Hsps have been associated with fluctuations in environmental temperatures in mussels and marine snails (Chapple et al., 1998; Hofmann and Somero, 1995; Tomanek and Somero, 1999, Minier et al., 2000; Hofmann et al., 2002) and enhanced thermal tolerance in oysters (Clegg et al., 1998, Piano et al., 2002). However, as underlined by Encomio and Chu (2005), it has not been unequivocally demonstrated that seasonal variation in Hsps corresponds directly to seasonal temperature changes. These authors showed in Crassostrea virginica, that total amounts of Hsp70 did not correlate positively with seasonal variations in temperature. Similarly, subtidal mussels (Mytilus sp.) were shown to express higher levels of Hsp70 in winter than in summer (Roberts et al., 1997). Other factors such as salinity or disease were reported to alter Hsp expression (Shumway and Koehn, 1982; Werner and Hinton, 2000). In our study, we observed a small increase in mRNA levels of Hsp family members 
(Hsp70, IIsc72 and Hsp90) in whole soft tissue of oysters during the summer period but also high mRNA levels in the winter between January and April.

\section{5-CONCLUSION}

We did not find any evidence for any relationship between changes in these mRNA levels and oysters' exposure to liquid radioactive waste from the $A R E V A$ reprocessing plant in La Hague. The fact that those radionuclide releases result in a very small increase in radioactivity in oysters, especially compared with natural radioactivity, may be an explanation. However in this in situ approach, because of the complexity of the natural environment, we cannot rule out the possibility that other parameters may have masked the impact of radioactive discharges. Our data showed that, in the natural environment, mRNA levels of stress-inducible genes in oysters fluctuate seasonally. This provided knowledge of variations in these genes' expression levels, especially scasonal fluctuations and natural inter-individual variability. This was necessary preliminary work before we could tackle the "chronically low dose exposure" issue. On the basis of this knowledge, the next step is now to artificially expose oysters to radionuclides under laboratory conditions and to study the effects of chronic exposure to radionuclides on the mRNA levels of stress inducible genes. 


\section{REFERENCES}

Amiard JC, Amiard-Triquet C, Barka S, Pellerin J, Rainbow PS. Metallothioneins in aquatic invertebrates: their role in metal detoxification and their use as biomarkers. Aquat Toxicol 2006; 76: 160-202.

Andersen CL, Jensen JL, Orntoft TF. Normalization of Real-Time Quantitative Reverse Transcription-PCR Data: A Model-Based Variance Estimation Approach to Identify Genes Suited for Normalization, Applied to Bladder and Colon Cancer Data Sets. Cancer Res 2004; 64: 5245-5250.

Anderson RS, Patel KM, Rocsijadi G. Oyster metallothionein as an oxyradical scavenger: implications for hemocytc defense responses. Dev Comp Immunol 1999; 23: 443-449.

Bailly du Bois P, Dumas F. Fast hydrodynamic model for medium- and long-term dispersion in seawater in the English Channel and southern North Sea, qualitative and quantitative validation by radionuclide tracers. Ocean Modelling 2005; 9: 169-210.

Baptist JP, Wolfe DA, Colby DR. Effects of chronic gamma radiation on the growth and survival of juvenile clams (Mercenaria mercenaria) and scallops (Argopecten irradians). I Icalth Phys 1975; 30: 79-82.

Baudrimont M, Lemaire-Gony S, Ribeyre F, Métivaud J, Boudou A. Seasonal variations of metallothionein concentrations in the Asiatic clam (Corbicula fluminea). Comp Biochem Physiol C, Pharmacol Toxicol Fndocrinol 1997; 118: 361-367.

Bebianno MJ, Company R, Serafim A, Camus L, Cosson RP, Fiala-Medoni A. Antioxidant systems and lipid peroxidation in Bathymodiolus azoricus from Mid-Atlantic Ridge hydrothermal vent fields. Aquat Toxicol 2005; 75: 354-373.

Bodin N, Burgeot T, Bocquené G, Menard D, Stanisière JY, Minier C, Boutet I, Amat A, Cherel Y, Budzinski II. Seasonal variations of a battery of biomarkers and physiological indices for the mussel Mytilus galloprovincialis transplanted into the northwest Mediterranean Sea. Comp Biochem Physiol C, Pharmacol Toxicol Fndocrinol 2004; 138: 411-427.

Bustin SA, Benes V, Nolan T, Pfaffl MW. Quantitative real-time RT-PCR - a perspective. J Mol Fndocrinol 2005; 34: 597-601.

Cai L, Satoh M, Tohyama C, Cherian MG. Metallothionein in radiation exposure: its induction and protective role. Toxicology 1999; 132: 85-98.

Cai L, Cherian MG. Zinc-metallothionein protects from DNA damage induced by radiation better than glutathione and copper- or cadmium-metallothioneins. Toxicol Lett 2003; 136: 193-198.

Calini V, Urani C, Camatini M. Overexpression of HSP70 is induced by ionizing radiation in C3H 10T1/2 cells and protects from DNA damage. Toxicol In Vitro 2003; 17: 561566.

Cavaletto M, Ghezzi A, Burlando B, Evangelisti V, Ceratto N, Viarengo A. Effect of hydrogen peroxide on antioxidant enzymes and metallothionein level in the digestive gland of Mytilus galloprovincialis. Comp Biochem Physiol C Toxicol Pharmacol 2002; 131: 447-455.

Chapple JP, Smerdon GR, Berry RJ, Hawkins AJS. Seasonal changes in stress-70 protein levels reflect thermal tolerance in the marine bivalve Mytilus edulis L. J Exp Mar Biol Ecol 1998; 229: 53-68.

Chubatsu LS, Meneghini R. Metallothionein protects DNA from oxidative damage. Biochem J 1993; 291: 193-198. 
Clegg JS, Uhlinger KR, Jackson SA, Cherr GN, Rifkin E, Fricdman CS. Induced thermotolerance and the heat shock protein-70 family in the Pacific oyster Crassostrea gigas. Mol Marine Biol Biotechnol 1998; 7: 21-30.

Cooley JL. Effects of chronic environmental radiation on a natural population of the aquatic snail Physa heterostropha. Radiat Res 1973; 54: 130-140.

Dalton T, Palmiter RD, Andrews GK. Transcriptional induction of the mouse metallothionein-I gene in hydrogen peroxide-treated IIepa cells involves a composite major late transcription factory antioxidant response element and metal response promoter elements. Nucl Acid Res 1994; 22: 5016-5023.

Davidoff $\Lambda \mathrm{M}$, Iglehart JD, Marks JR. Immune response to p53 is dependent upon p53/HSP70 complexes in breast cancers. Proc Natl Acad Sci U.S.A. 1992; 89: 3439-3442.

Ehrhart JC, Duthu A, Ullrich S, Appella E, May P. Specific interaction between a subset of the p53 protein family and heat shock proteins hsp $72 / \mathrm{hsc} 73$ in a human osteosarcoma cell line. Oncogene 1988; 3: 595-603.

Encomio VG, Chu F-LE. Seasonal variation of heat shock protein 70 in eastern oysters (Crassostrea virginica) infected with Perkinsus marinus (Dermo). J Shellfish Res 2005; 24: 167-175.

Fiévet B, Plet D. Estimating biological half-lives of radionuclides in marine compartments from environmental time-series measurements. J Environ Radioact 2003; 65: 91-107.

Fiévet B, Germain P. Observatoire Marin Atlantique - Manche. Bilan des résultats de mesure par spectrométrie gamma entre 1993 et 2003. IRSN report DEI/SECRE 2004-018, $2004,86 \mathrm{pp}$.

Fiévet B, Voiseux C, Rozet M, Masson M, Bailly du Bois P. Transfer of radiocarbon liquid relcases from the AREVA La Hague spent fuel reprocessing plant in the English Channel. J Envir Radioact (in press).

Geffard A, Amiard-Triquet C, Amiard JC, Mouneyrac C. Temporal variations of metallothionein and metal concentrations in the digestive gland of oysters Crassostrea gigas from a clean and a metal-rich sites. Biomarkers 2001; 6: 91-107.

Geffard A, Amiard JC, Amiard-Triquet C. Use of metallothionein in gills from oysters (Crassostrea gigas) as a biomarker: seasonal and intersite fluctuations. Biomarkers 2002; 7: 123-137.

Geffard A, Amiard-Triquet C, Amiard JC. Do seasonal changes interfere with metallothionein induction by metals in mussels Mytilus edulis? Ecotox Env Saf 2005; 61: 209-220.

Goidin D, Mamessier A, Staquet MJ, Schmitt D, Berthier-Vergnes O. Ribosomal 18S RNA Prevails over Glyceraldehyde-3-Phosphate Dehydrogenase and [beta]-Actin Genes as Internal Standard for Quantitative Comparison of mRNA Levels in Invasive and Noninvasive ILuman Melanoma Cell Subpopulations. Anal Biochem 2001; 295: 17 21.

Greenstock CI, Jinot CP, Whitchouse RP, Sargent MD. DNA radiation damage and its modification by metallothionein. Free Radic Res Commun 1987; 2: 233-239.

Guo G, Wang T, Tamae D, Ogi J, Khaletskiy A, Li Z, Li JJ, Longmate JA, Yan-Sanders Y, Lyn-Cook BD, Weydert C, Spitz DR, Oberley LW, Huang TT. Manganese superoxide dismutase-mediated gene expression in radiation-induced adaptive responses. Mol Cell Biol 2003; 23: 2362-2378.

Hagger JA, Atienzar FA, Jha AN. Genotoxic, cytotoxic, developmental and survival effects of tritiated water in the early life stages of the marine mollusc, Mytilus edulis. Aquat Toxicol 2005; 74: 205-217.

Heude-Berthelin C. Etude du métabolisme du glycogène chez l'huître creuse Crassostrea gigas. Impact sur la reproduction et les mortalités estivales. University of Caen/BasseNormandie, Caen, 2000, 156 pp. 
Hinton, T.G.. Determining significant endpoints for ecological risk analyses. University of Georgia, Savannah River Ecology Laboratory, 2000, $27 \mathrm{pp}$.

Hofmann G, Somero G. Evidence for protein damage at environmental temperatures: seasonal changes in levels of ubiquitin conjugates and hsp70 in the intertidal mussel Mytilus trossulus. J Exp Biol 1995; 198: 1509-1518.

Hofmann GE, Buckley BA, Place SP, Zippay ML. Molecular chaperones in ectothermic marine animals: Biochemical function and gene expression. Integr Comp Biol 2002; 42: 808-814.

Huggett J, Dheda K, Bustin S, Zumla A. Real-time RT-PCR normalisation; strategies and considerations. Genes Immun 2005; 6: 279-284.

Ifremer. Résultats de la Surveillance de la Qualité du Milieu Marin Littoral, Edition 2005. Itaute et Basse-Normandie. Ifremer, Laboratoires Environnement et Ressources de Normandie, 2005a, 82 pp.

Ifremer. Résultats de la Surveillance de la Qualité du Milieu Marin Littoral, Edition 2005. Ile et Vilaine et Côtes d'Armor. Ifremer, Laboratoire Environnement Ressources de SaintMalo, 2005b, $85 \mathrm{pp}$.

Ifremer. Résultats de la Surveillance de la Qualité du Milicu Marin Littoral, Edition 2005. Morbihan, Loire-Atlantique, Vendée nord. Ifremer, Iaboratoire côtier Morbihan et Pays de Loire, 2005c, $112 \mathrm{pp}$.

Irato P, Santovito G, Cassini A, Piccinni E, Albergoni V. Metal accumulation and binding protein induction in Mytilus galloprovincialis, Scapharca inaequivalvis and Tapes philippinarum from the Lagoon of Venice. Arch Environ Contam Toxicol 2003; 44: $476-484$.

Jha AN, Dogra Y, Tumer $\Lambda$, Millward GE. Impact of low doses of tritium on the marine mussel, Mytilus edulis: Genotoxic effects and tissuc-specific bioconcentration. Mutat Res 2005; 586: 47-57.

Kang CM, Park KP, Cho CK, Sco JS, Park WY, Lee SJ, Lee YS. Hspa4 (HSP70) is involved in the radioadaptive response: results from mouse splenocytes. Radiat Res 2002; 157 : $650-655$.

Kim B-R, Nam II-Y, Kim S-U, Kim S-I, Chang Y-J. Normalization of reverse transcription quantitative-PCR with housekeeping genes in rice. Biotechnol Lett 2003; 25: 18691872.

Lango-Reynoso F, Chavez-Villalba J, Cochard JC, Le Pennec M. Oocyte size, a means to evaluate the gametogenic development of the Pacific oyster, Crassostrea gigas (Thunberg). Aquaculture 2000; 190: 183-199.

Leung KMY, Furness RW. Metallothionein induction and condition index of dogwhelks Nucella lapillus (I.) exposed to cadmium and hydrogen peroxide. Chemosphere 2001; 44: 321-325.

Leung KMY, Svavarsson J, Crane M, Morritt D. Influence of static and fluctuating salinity on cadmium uptake and metallothionein expression by the dogwhelk Nucella lapillus (L.). J Exp Mar Biol Ecol 2002; 274: 175-189

Matsumoto H, Wang X, Ohnishi T. Binding between wild-type p53 and hsp72 accumulated after UV and gamma-ray irradiation. Cancer I.ett 1995; 92, 127-133.

Mihok S. Chronic exposure to gamma radiation of wild populations of meadow voles (Microtus pennsylvanicus). J Environ Radioact 2004; 75: 233-266.

Minier C, Borghi V, Moore MN, Porte C. Seasonal variation of MXR and stress proteins in the common mussel, Mytilus galloprovincialis. Aquat Toxicol 2000; 50: 167-176.

Otero G, Avila MA, Emfietzoglou D, Clerch L.B, Massaro D, Notario V. Increased manganese superoxide dismutase activity, protein, and mRNA levels and concurrent 
induction of tumor necrosis factor alpha in radiation-initiated Syrian hamster cells. Mol Carcinog 1996; 17: 175-180.

Piano $A, \Lambda$ sirelli $\mathrm{C}$, Caselli $\mathrm{F}$, Fabbri $\mathrm{E}$. Hsp70 expression in thermally stressed Ostrea edulis, a commercially important oyster in Europe. Cell Stress Chaperones 2002; 7: 250-257.

Rackham BD, Woodhead DS. Effects of chronic gamma-irradiation on the gonads of adult Ameca splendens (Osteichthyes: Teleostei). Int J Radiat Biol 1984; 45: 645-656.

Ringwood $\mathrm{AH}$, Conners DF, DiNovo $\Lambda$. The effects of copper exposures on cellular responses in oysters. Mar Environ Res 1998; 46: 591-595.

Roberts DA, Hofmann GE, Somero GN. Heat-shock protein expression in Mytilus californianus: Acclimatization (seasonal and tidal-height comparisons) and acclimation effects. Biol Bull 1997; 192: 309-320.

Roesijadi G, Brubacher LI, Unger ME, Anderson RS. Metallothionein mRNA induction and generation of reactive oxygen species in molluscan hemocytes exposed to cadmium in vitro. Comp Biochem Physiol C, Pharmacol Toxicol Fndocrinol 1997; 118: 171-176.

Ropenga A, Chapel A, Vandamme M, Griffiths NM. Use of reference gene expression in rat distal colon after radiation exposure: $\Lambda$ caveat. Radiat Res $2004 ; 161,597$.

Sato M, Bremner I. Oxygen free radicals and metallothionein. Free Radic Biol Med 1993; 14: 325-337.

Serafim A, Company RM, Bebianno MJ, Langston WJ. Effect of temperature and size on metallothionein synthesis in the gill of Mytilus galloprovincialis exposed to cadmium. Mar Environ Res 2002; 54: 361-365.

Sheehan D, Power A. Effects of seasonality on xenobiotic and antioxidant defence mechanisms of bivalve molluscs. Comp Biochem Physiol C, Pharmacol Toxicol Endocrinol 1999; 123: 193-199.

Sierra-Rivera E, Voorhees GJ, Freeman ML. Gamma irradiation increases hsp-70 in Chinese hamster ovary cells. Radiat Res 1993; 135: 40-45.

Shumway SE, Koehn RK. Oxygen consumption in the American oyster Crassostrea virginica. Mar Ecol Prog Ser 1982; 9: 59-68.

Solé M, Porte C, Albaiges J. The use of biomarkers for assessing the effects of organic pollution in mussels. Sci Total Environ 1995; 159: 147-153.

Tanguy A, Boutet I, Bonhomme F, Boudry P, Moraga D. Polymorphism of metallothionein genes in the pacific oyster Crassostrea gigas as a biomarker of response to metal exposure. Biomarkers 2002; 7: 439-450.

Thellin O, Zorzi W, Lakaye B, De Borman B, Coumans B, Hennen G, Grisar T, Igout A, Heinen E. Housekeeping genes as internal standards: use and limits. J Biotechnol 1999; 75: 291-295.

Theodorakis CW, Shugart LR. Genetic ecotoxicology III: the relationship between DNA strand breaks and genotype in mosquito fish exposed to radiation. Ecotoxicology $1998 ; 7: 227-236$.

Tomanek LS, Somero GN. Evolutionary and acclimation induced variation in the heat shock responses on congeneric marine snails (genus Tegula) from different thermal habitats: implications for limits of thermotolerance and biogeography. J Exp Biol 1999; 202: 2925-2936.

Viarengo A, Cancsi L, Pertica M, Livingstone DR. Seasonal variations in the antioxidant defence systems and lipid peroxidation of the digestive gland of mussels. Comp Biochem Physiol C, Pharmacol Toxicol Endocrinol 1991; 100: 187-190.

Viarengo A, Burlando B, Cavaletto M, Marchi B, Ponzano E, Blasco J. Role of metallothionein against oxidative stress in the mussel Mytilus galloprovincialis. Am $\mathbf{J}$ Physiol 1999; 277: R1612-1619. 
Viarengo A, Burlando B, Ceratto N, Panfoli I. Antioxidant role of metallothioneins: a comparative overview. Cell Mol Biol 2000; 46: 407-417.

Werner I, Hinton DE. Spatial profiles of hsp70 proteins in Asian clam (Potamocorbula amurensis) in northern San Francisco Bay may be linked to natural rather than anthropogenic stressors. Mar Environ Res 2000; 50: 3379-3384.

Wong MI, Medrano JF. Real-time PCR for mRNA quantitation. BioTechniques 2005; 39: 75-85.

Woodhead DS. The effects of chronic irradiation on the breeding performance of the guppy, Poecilia reticulata (Osteichtyes: Teleostei). Int J Radiat Biol 1977; 32: 1-22.

Yamaoka K, Sato EF, Utsumi K. Induction of two species of superoxide dismutase in some organs of rats by low dose X-irradiation. Physiol Chem Phys Med NMR 1994; 26: 205-214.

You HJ, Oh DH, Choi CY, Lee DG, Hahm KS, Moon AR, Jeong HG. Protective effect of metallothionein-III on DNA damage in response to reactive oxygen species. Biochim Biophys Acta 2002; 1573: 33-38.

\section{ACKNOWLEDGEMENTS}

Emilie FARCY was supported in part by a fellowship from "Région Basse-Normandie". This study was part of the ENVIRHOM research programme, supported by the Institute for Radioprotection and Nuclear Safety (IRSN). The authors would like to thank Iuc Solier (Laboratoire de Radioécologic de Cherbourg Octeville, IRSN) for gamma spectrometry analysis and the Laboratoire de Mesure de la Radioactivite dans l'Environnement (IRSN) for alpha emitter radionuclide analysis in oyster samples. The authors are indebted to Juliette Royer and I aurenee Challier (Laboratoire de Biologie et Biotechnologies Marine, University of Caen - Basse Normandie) for their assistance with statistics and principal component analysis. 


\section{FIGURE CAPTIONS}

Table 1: Primer sequences and accession number.

Table 2: Whole soft tissue concentrations of artificial gamma emitter radionuclides in oysters from St-Vaast (STV), expressed in Bq. $\mathrm{kg}^{-1}$ dry weight \pm measurement uncertainty. Values below the detection limit are indicated by the symbol - .

Table 3: Whole soft tissue concentrations of transuranic radionuclides in oysters from Carnac (CRC), Cancale (CCI) and St-Vaast (STV), expressed in Bq. $\mathrm{kg}^{-1}$ dry weight \pm measurement uncertainty. Values below the detection limit are indicated by the symbol $<$.

Table 4: Correlation matrix on axes 1 and 2. In bold: values $>0.7$. The correlation is given by the angle between the descriptor and axis, the closer to unity (unsigned value), the stronger the correlation. The five genes explained component one well.

Table 5: Matrix of the test values for the illustrative parameter. For each axis and each illustrative parameter, the test value expresses the statistical significance of the parameter's coordinate on this axis. In bold: significant values at the level of significance alpha $=0.05$, which implies absolute values $>2.0$.

Figure 1: Map showing the AREVA reprocessing plant and the sampling locations along the French coast.

Figure 2: Monthly values of seawater temperature in Goury-I Iarbour near St-Vaast. In grey: the period with a temperature $<10^{\circ} \mathrm{C}$. The grey bands indicate the periods with seawater temperature below $10^{\circ} \mathrm{C}$.

Figure 3: Hsp70 (a), Hsc72 (b), Hsp90 (c), SOD (d) and MT (e) mRNA levels in gills (dotted line) and whole soft tissues (solid line) in oysters collected monthly in STV between January 2004 and September 2005. Symbol * means a statistically significant difference $(\mathrm{p}<0.05)$ between the two paired data (Mann-Whitney test, $n=4$ pools of 5 individuals) and the associated value corresponds to their ratio. The grey bands indicate the periods displaying seawater temperature below $10^{\circ} \mathrm{C}$.

Figure 4: mRNA levels of Hsp70 (a), Hsc72 (b), Hsp90 (c), SOD (d) and MT (e) in oysters collected quarterly in CRC (white), CCL (hatched), $\triangle \mathrm{SN}$ (grey) and STV (black). * placed above a bar for locations exposed to radionuclide releases (STV, ASN, CCL) means a statistically significant difference in mRNA level $(\mathrm{p}<0.05)$ between this location and the reference site (CRC) (Mann-Whitney test, $n=4$ pools of 5 individuals).

Figure 5: Correlation circle for the variables (genes) on axes 1 and 2.

Figure 6: Principal component analysis biplot. The size of the symbol is proportional to the contribution (squared cosines of the variable). Axis 1 clearly separates data as a function of time and this first axis showed a clear strong contrast between winter and summer data. 


\section{TABLES}

Table 1: Primer sequences and accession number.

\begin{tabular}{|c|c|c|c|}
\hline $\begin{array}{c}\text { Gene } \\
\text { (or rRNA) }\end{array}$ & $\begin{array}{l}\text { GenBank } \\
\text { accession \# }\end{array}$ & Forward Primer & Reverse Primer \\
\hline *actin & AF026063 & $5^{\prime}$ GCCCTGGACTTCGAACAA $3^{\prime}$ & $5^{\prime}$ CGTTGCCAATGGTGATGA $3^{\prime}$ \\
\hline$* 18 \mathrm{~S}$ & AB064942 & $5^{\prime}$ CGGGGAGGTAGTGAC GAA $3^{\prime}$ & $5^{\prime}$ ACCAGACTTGCCCTCCAA $3^{\prime}$ \\
\hline *GAPDH & AJ544886 & $5^{\prime}$ TTGTCTTGCCCCTCTTGC $3^{\prime}$ & $5^{\prime}$ CGCCAATCCTTGTTGCTT $3^{\prime}$ \\
\hline Hsp70 & AJ305315 & $5^{\prime}$ AGCAAGCCAGCACAGCA $3^{\prime}$ & $5^{\prime}$ GCGATGATTTCCACC'TC $3^{\prime}$ \\
\hline Hsc72 & AF144646 & $5^{\prime}$ GAGGATCGCAGCCAAGAA $3^{\prime}$ & $5^{\prime}$ TATCGCCCTCGCTGATCT $3^{\prime}$ \\
\hline Hsp90 & AJ431681 & $5^{\prime}$ GGAGAGCAAAACCCTCACC $3^{\prime}$ & $5^{\prime} \quad$ TGGCAATGGTTCCAAGGT $3^{\prime}$ \\
\hline$* *$ SOD & AJ496219 & $5^{\prime}$ AACCCC'TCAACAAAGAGCA $3^{\prime}$ & $5^{\prime}$ TTTGGCGACACCGTCTTC $3^{\prime}$ \\
\hline ***MT & $\begin{array}{l}\text { AJ243263 } \\
\text { AJ242657 }\end{array}$ & 5' GGACCGGAAAACTGCAAA 3' & $5^{\prime}$ CCAGTGCATCCTTTACCACA $3^{\prime}$ \\
\hline
\end{tabular}

* used to normalize mRNA.

** The amino acid translation of the Genbank \#AJ496219 sequence is highly homologous to a Cu-Zn SOD.

*** This pair of primers did not discriminate between two identified members of oyster MTs: MT1 (accession \# AJ243263) and MT2 (accession \# AJ242657). 
Table 2: Whole soft tissue concentrations (in Bq. $\mathrm{kg}^{-1}$ dry weight) of artificial gamma emitter radionuclides in oysters from St-Vaast.

\begin{tabular}{|c|c|c|}
\hline Month & ${ }^{60}$ Co & ${ }^{137}$ Cs \\
\hline Jul-02 & $0.18 \pm 0.17$ & - \\
\hline Aug-02 & $0.19 \pm 0.14$ & - \\
\hline Sep-02 & $0.18 \pm 0.17$ & - \\
\hline Dec-02 & - & $0.50 \pm 0.40$ \\
\hline Apr-03 & $0.20 \pm 0.14$ & $0.16 \pm 0.14$ \\
\hline Jul-03 & - & $0.34 \pm 0.13$ \\
\hline Aug-03 & $0.14 \pm 0.12$ & - \\
\hline Sep-03 & $0.12 \pm 0.11$ & - \\
\hline Nov-03 & $0.14 \pm 0.12$ & - \\
\hline Dec-03 & $0.16 \pm 0.13$ & - \\
\hline Mar-04 & $0.23 \pm 0.14$ & - \\
\hline
\end{tabular}


Table 3: Whole soft tissue concentrations (in Bq. $\mathrm{kg}^{-1}$ dry weight) of transuranic radionuclides in oysters from Carnac (CRC), Cancale (CCL) and St-Vaast (STV).

\begin{tabular}{|c|c|c|c|c|c|}
\hline Location & Month & ${ }^{241} \mathrm{Am}$ & ${ }^{244} \mathrm{Cm}$ & ${ }^{238} \mathrm{Pu}$ & ${ }^{239} \mathrm{Pu}+{ }^{240} \mathrm{Pu}$ \\
\hline CRC & Jun-04 & $0.0011 \pm 0.0003$ & $<0.0001$ & $0.0004 \pm 0.0002$ & $0.0101 \pm 0.0009$ \\
\hline CCL & Jun-04 & $0.0167 \pm 0.0019$ & $0.0018 \pm 0.0004$ & $0.0086 \pm 0.0011$ & $0.0280 \pm 0.0024$ \\
\hline STV & Aug-02 & $0.0289 \pm 0.0051$ & $0.0042 \pm 0.0019$ & $0.0073 \pm 0.0020$ & $0.0153 \pm 0.0029$ \\
\hline STV & Dec-02 & $0.0042 \pm 0.0005$ & $0.0008 \pm 0.0002$ & $0.0100 \pm 0.0020$ & $0.0255 \pm 0.0033$ \\
\hline STV & Jun-04 & $0.0152 \pm 0.002$ & $0.0021 \pm 0.0006$ & $0.0105 \pm 0.0140$ & $0.0273 \pm 0.0024$ \\
\hline
\end{tabular}


Table 4: Correlation coefficient between mRNA levels in STV and temperature of the seawater in Goury Harbour.

\begin{tabular}{|c|c|c|}
\hline$r$ & Whole soft tissue & Gills \\
\hline Hsp70 & -0.50 & -0.74 \\
\hline Hsc72 & -0.24 & -0.53 \\
\hline Hsp90 & -0.53 & -0.77 \\
\hline SOD & -0.18 & -0.68 \\
\hline MT & -0.64 & -0.66 \\
\hline
\end{tabular}


Table 5: Correlation matrix on axes 1 and 2.

\begin{tabular}{|c|c|c|}
\hline Variables & $\begin{array}{c}\text { Correlation } \\
\text { Variable-Factor } \\
\text { (axis 1) }\end{array}$ & $\begin{array}{c}\text { Correlation } \\
\text { Variable-Factor } \\
\text { (axis 2) }\end{array}$ \\
\hline Hsp70 & $\mathbf{- 0 . 8 7}$ & 0.33 \\
\hline Hsc72 & $\mathbf{- 0 . 8 3}$ & -0.03 \\
\hline Hsp90 & $\mathbf{- 0 . 7 1}$ & -0.52 \\
\hline SOD & $\mathbf{- 0 . 8 1}$ & 0.47 \\
\hline MT & $\mathbf{- 0 . 7 8}$ & -0.37 \\
\hline
\end{tabular}


Table 6: Matrix of the test values for the illustrative parameter.

\begin{tabular}{|c|c|c|}
\hline Descriptor & $\begin{array}{c}\text { Test-value } \\
\text { (axis 1) }\end{array}$ & $\begin{array}{c}\text { Test-Value } \\
\text { (axis 2) }\end{array}$ \\
\hline STV & 0.0 & 0. I \\
\hline CCL & -1.6 & -0.8 \\
\hline ASN & 0.4 & 0.8 \\
\hline CRC & 1.3 & -0.1 \\
\hline March 2004 & -0.3 & -0.2 \\
\hline June 2004 & $\mathbf{2 . 3}$ & -0.4 \\
\hline Sept 2004 & $\mathbf{4 . 1}$ & $\mathbf{- 2 . 9}$ \\
\hline Jan 2005 & $\mathbf{- 4 . 1}$ & $\mathbf{0 . 4}$ \\
\hline March 2005 & $\mathbf{- 6 . 1}$ & $\mathbf{0 . 9}$ \\
\hline June 2005 & $\mathbf{3 . 1}$ & $\mathbf{2 . 4}$ \\
\hline
\end{tabular}


Figure 1: Map showing the $\triangle R F V A$ reprocessing plant and the sampling locations along the French coast.

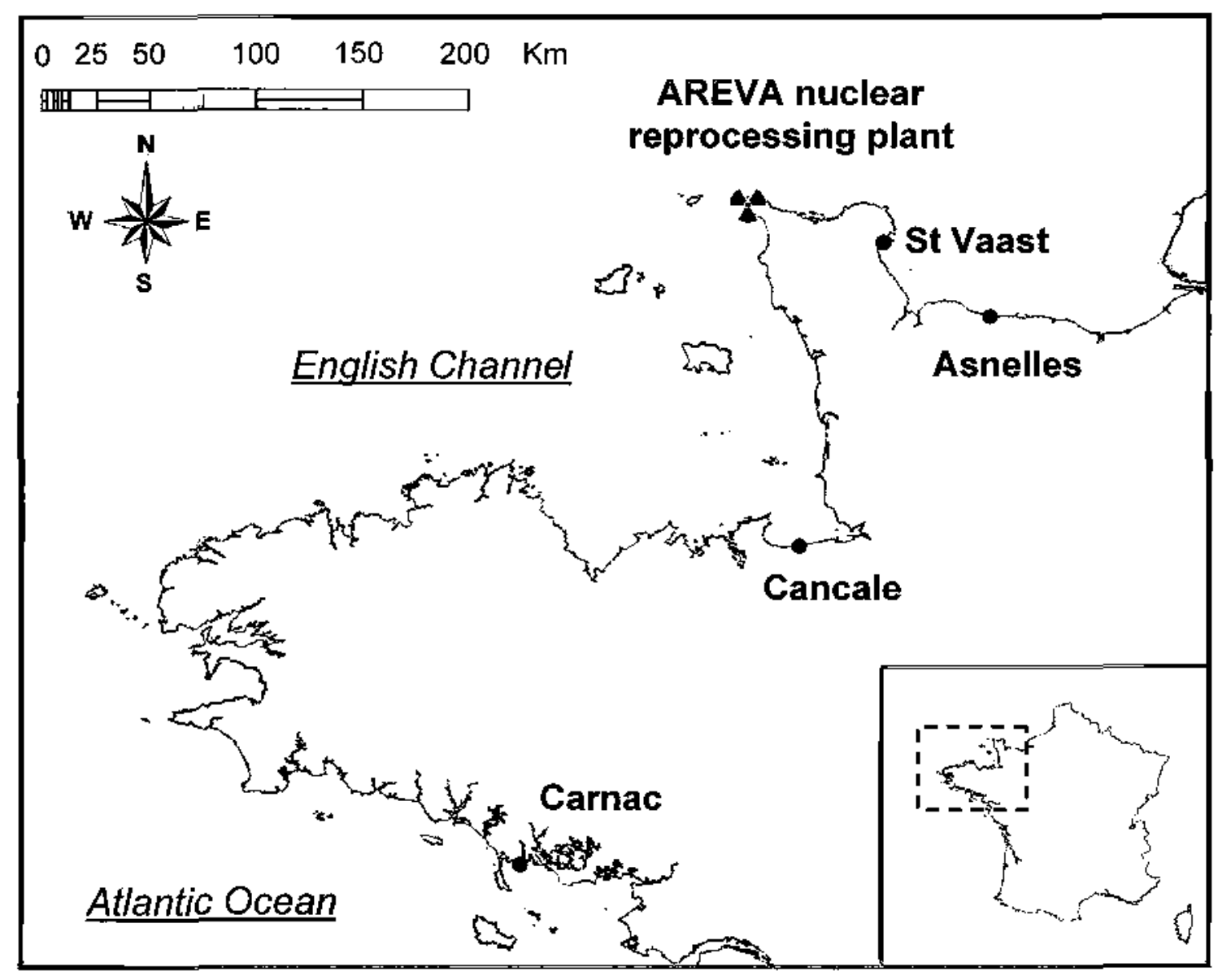



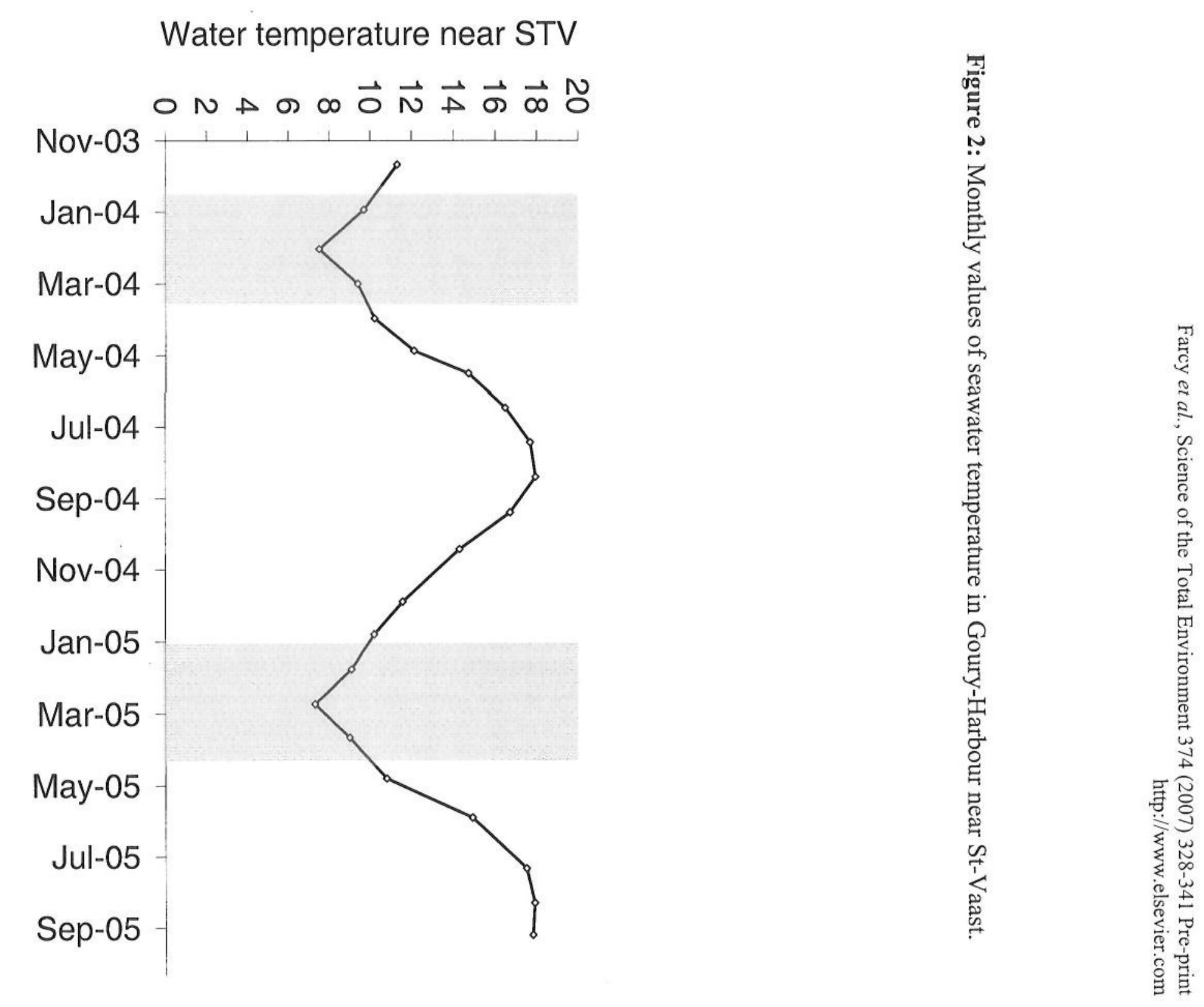
Figure 3: Hsp70 (a), Hsc72 (b), Hsp90 (c), SOD (d) and MT (e) mRNA levels in gills (dotted line) and whole soft tissues (solid line) in oysters collected monthly in STV between January 2004 and September 2005. * means a statistically significant difference $(\mathrm{p}<0.05)$ between the two paired data (Mann-Whitney test, $\mathrm{n}=4$ pools of 5 individuals) and the associated value corresponds to their ratio. The grey bands indicate the periods displaying seawater temperature below $10^{\circ} \mathrm{C}$.

a

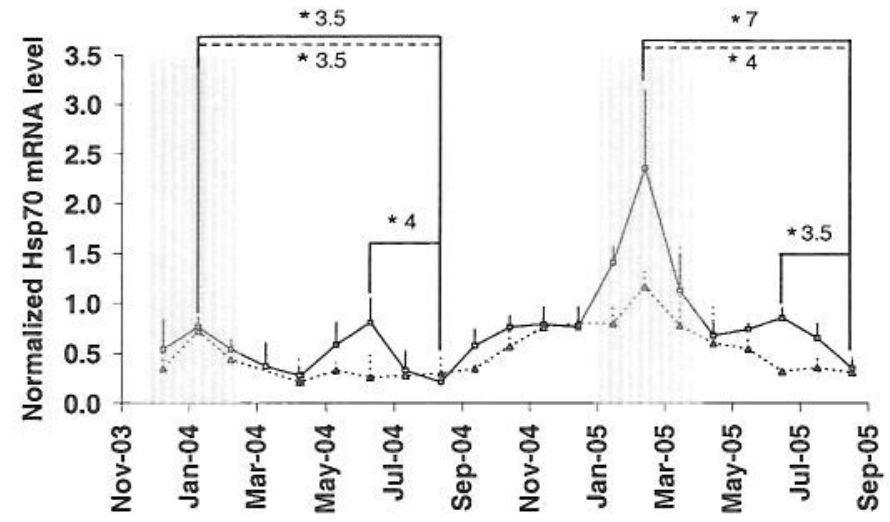

b

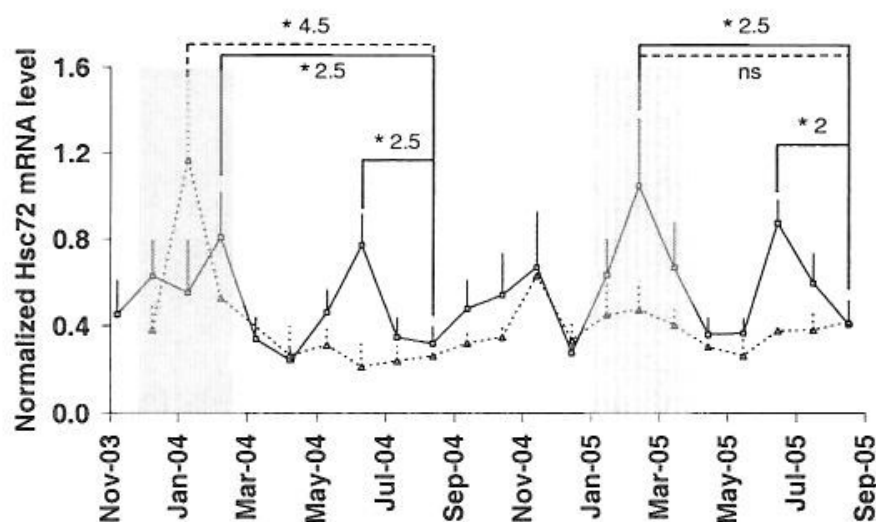

c

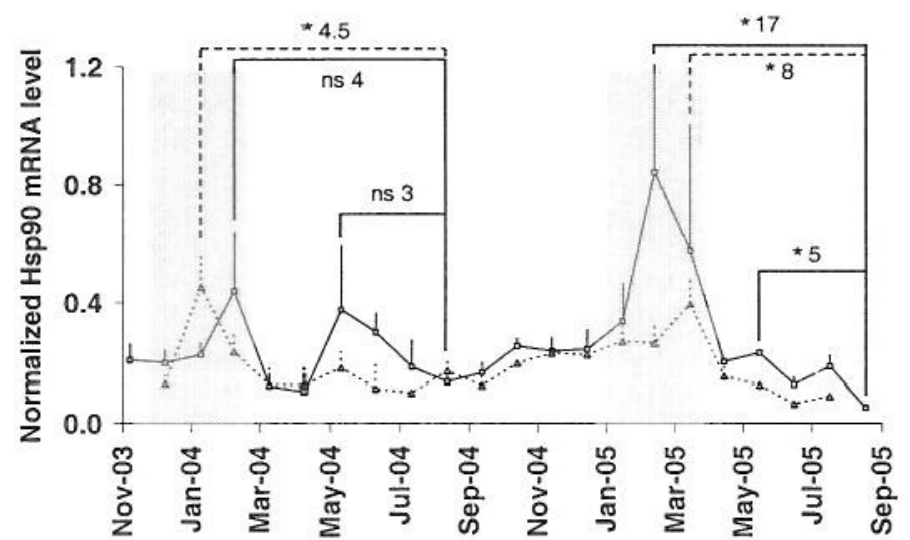

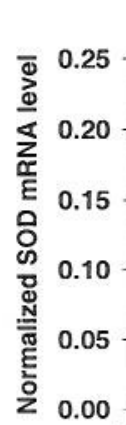
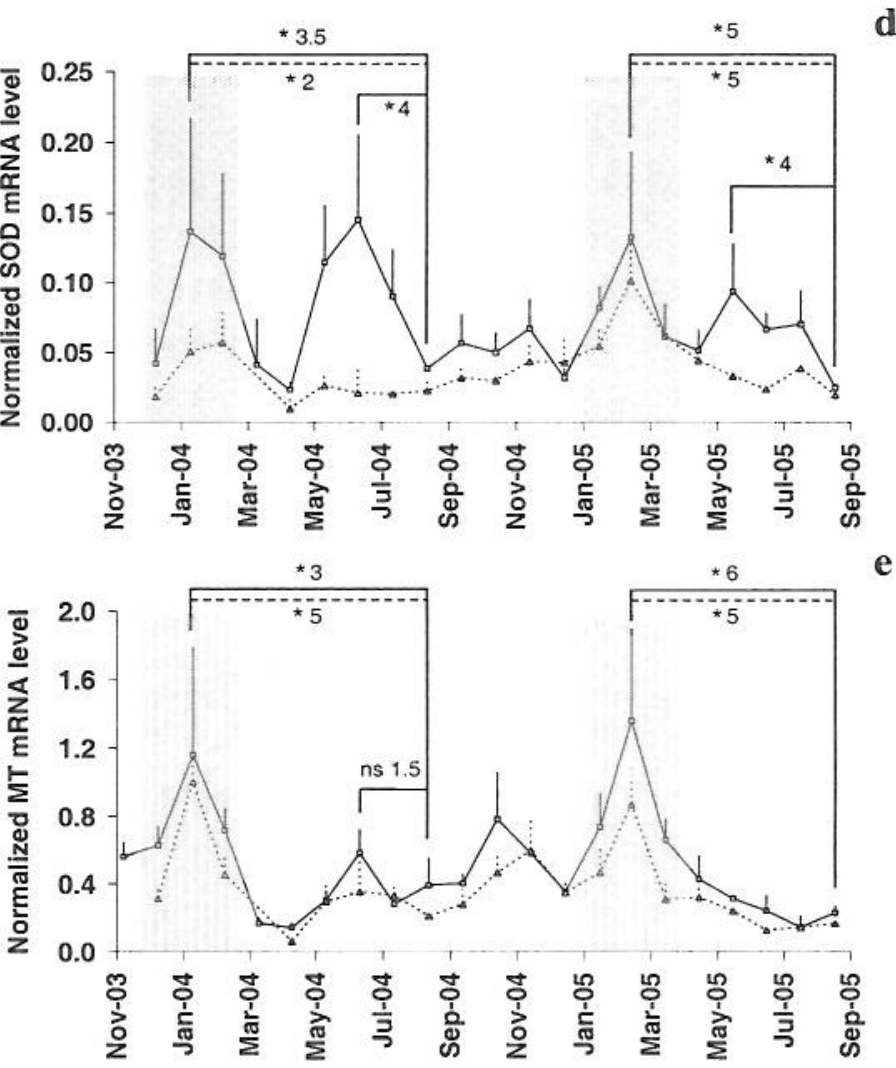
Figure 4: mRNA levels of Hsp70 (a), Hsc72 (b), Hsp90 (c), SOD (d) and MT (e) in oysters collected quarterly in CRC (white), CCL (hatched), ASN (grey) and STV (black). * placed above a bar for locations exposed to radionuclide releases (STV, ASN, CCL) means a statistically significant difference in mRNA level $(\mathrm{p}<0.05)$ between this location and the reference site (CRC) (Mann-Whitney test, $\mathrm{n}=4$ pools of 5 individuals).

a

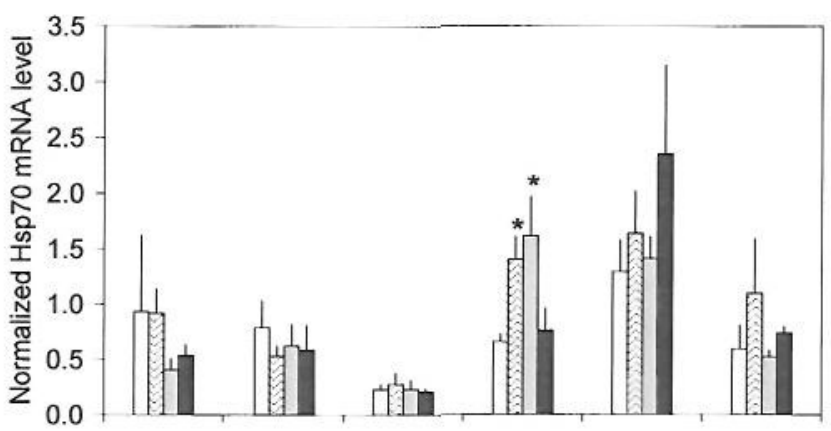

b

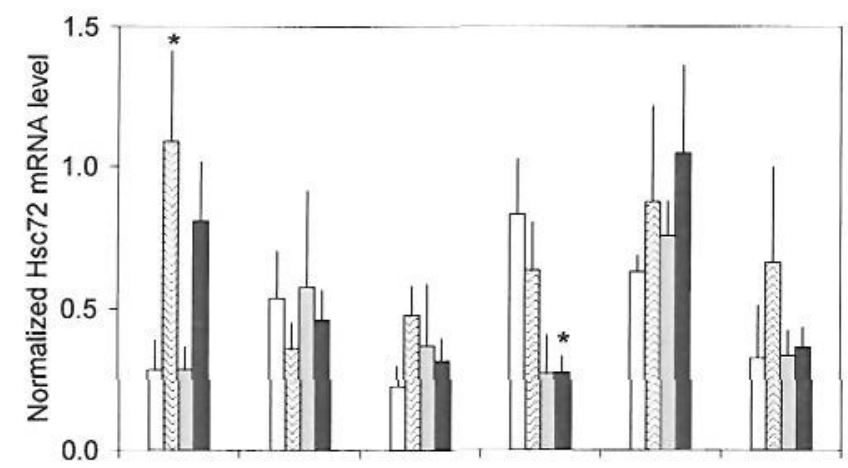

c

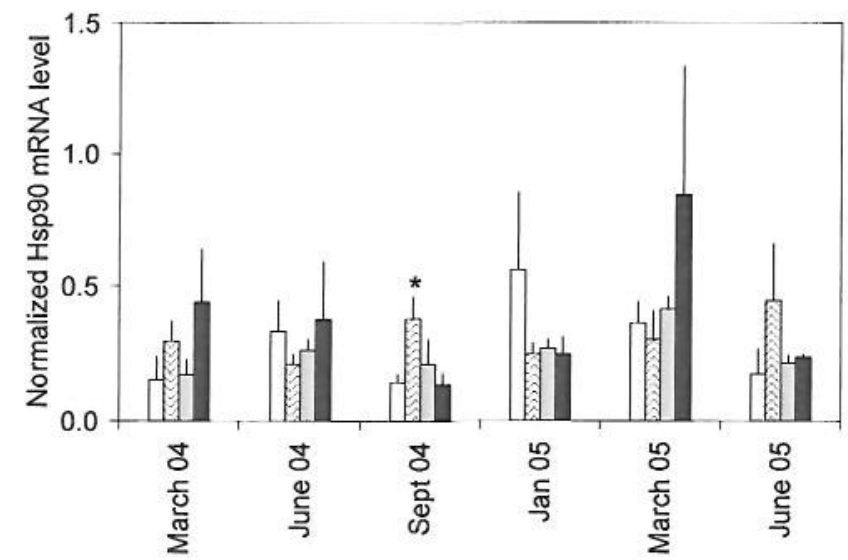

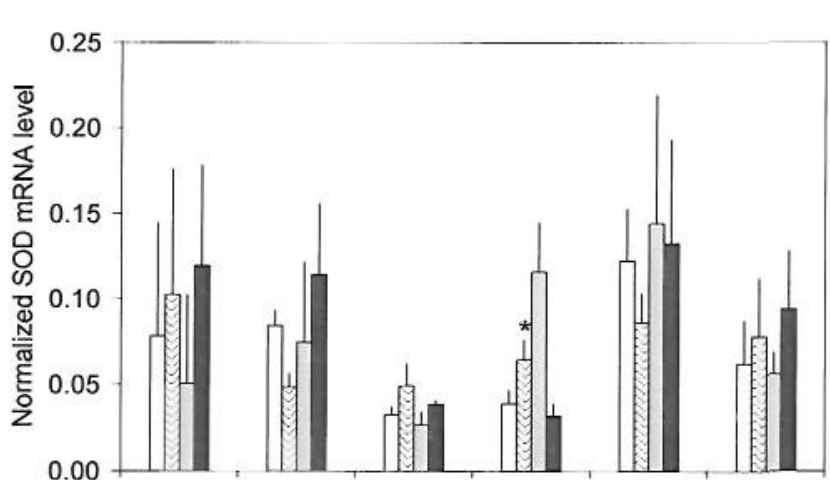

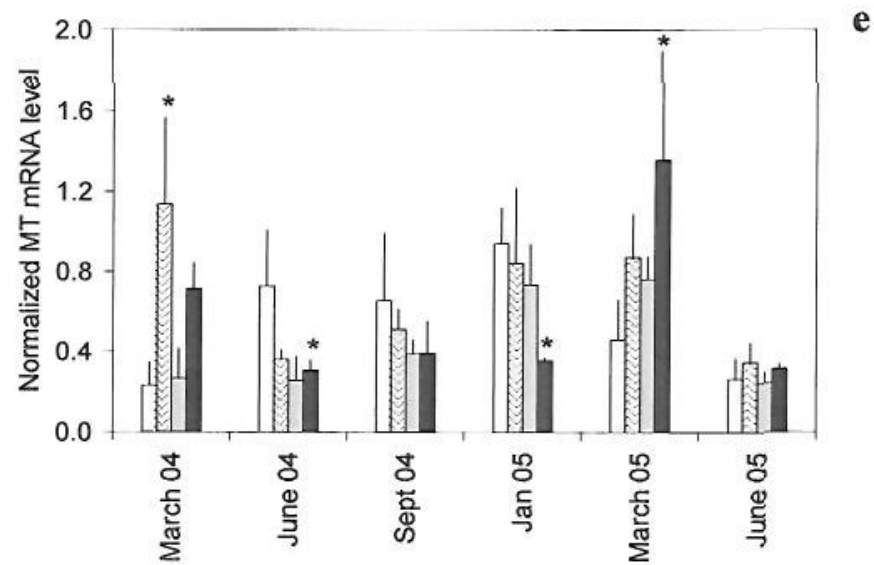


Figure 5: Correlation circle for the variables (genes) on axes 1 and 2.

Factor 2 - $14.74 \%$

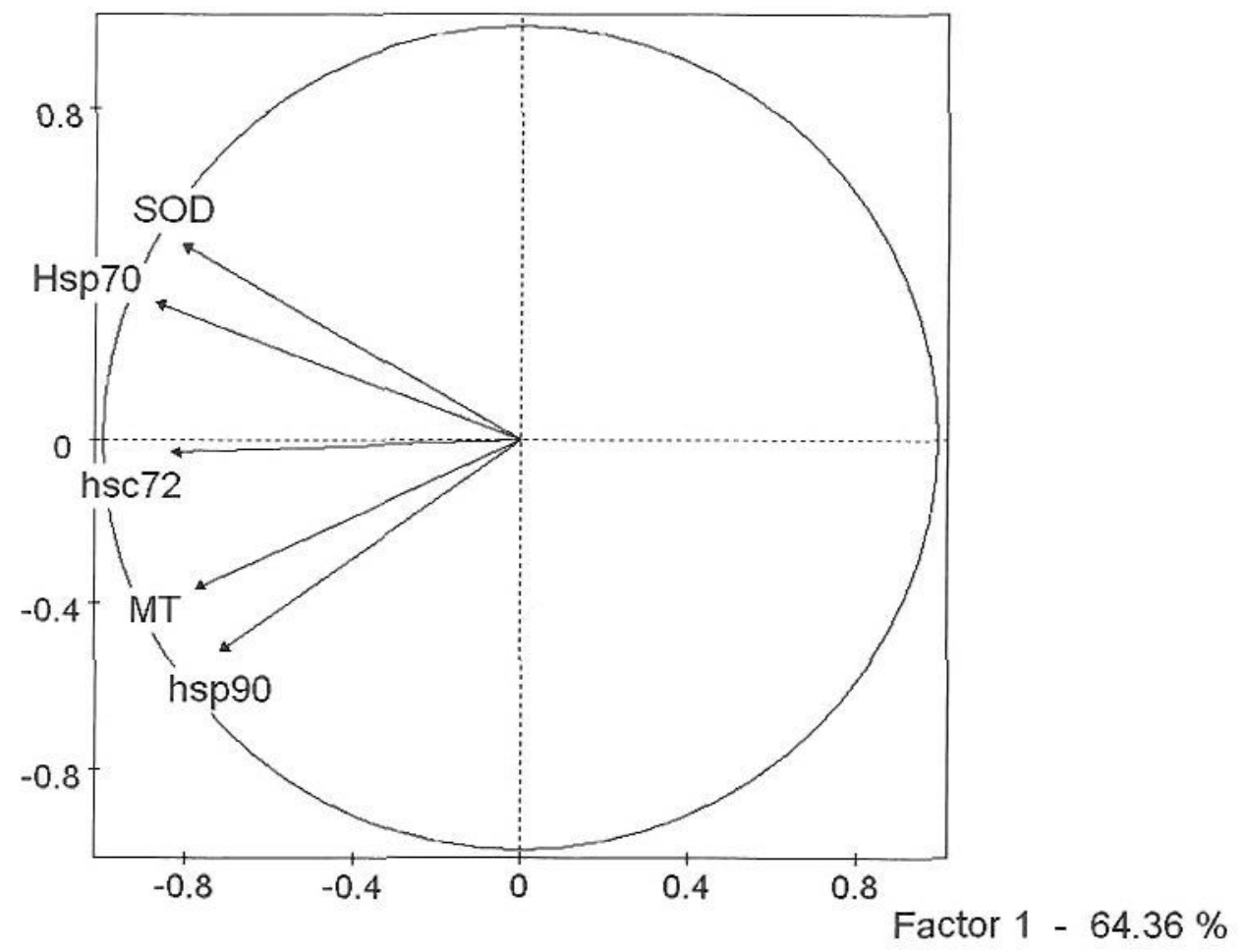


Figure 6: Principal component analysis biplot.

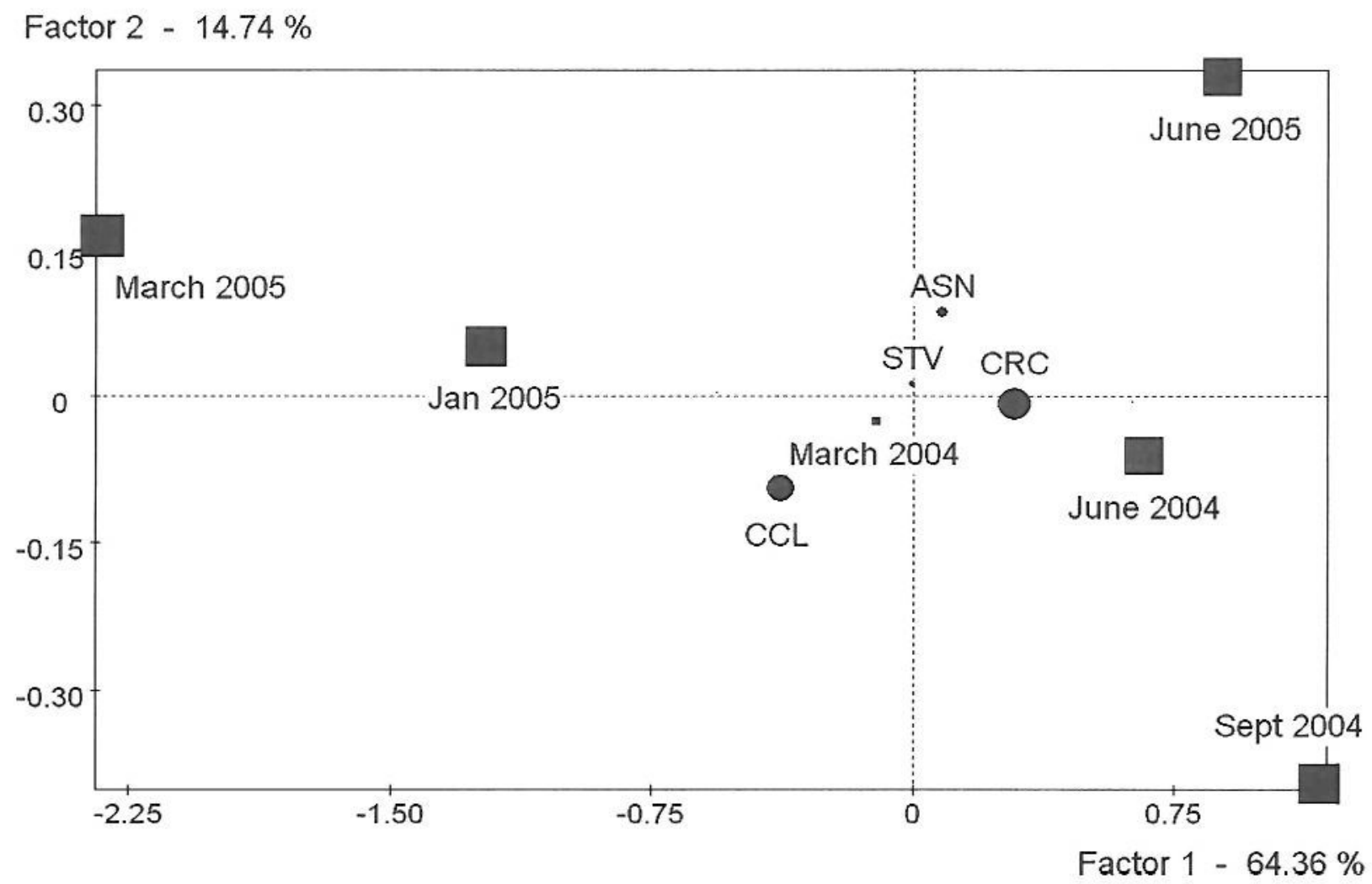

